\title{
CONSPIRACY THEORY AS A WORKING METHOD OF POLITICAL PROPAGANDA
}

\author{
Štefan Ižák ${ }^{1}$
}

\begin{abstract}
The paper Conspiracy theory as a working method of political propaganda deals with using of conspiracy theories by the specific (pro-Kremlin) kind of propaganda to spread certain ideological content. In the paper, the conspiracy theory The European Union organizes migration to Islamize Europe is analyzed. In the paper the internal logic of this conspiracy theory is revealed. The main objective of the paper is to analyze the argumentation strategies of this conspiracy theory and find out what kind of binarities analyzed conspiracy theory uses to legitimize its construction of reality. For the text analysis, a discourse analysis is chosen. This method allows me to analyze key discursive patterns characteristic for the set of collected news. The empirical part composed by the analysis of the research material follows the theoretical part of the paper, where the concept of conspiracy theory as the type of the discursive construction of reality and as a part of the political propaganda is presented. Results of research show that analyzed conspiracy theory disseminates concrete ideological views in favor of Eurosceptical, populist forces.
\end{abstract}

KEY WORDS: Conspiracy Theory, Propaganda, Migration, European Union, Discourse.

\section{INTRODUCTION}

In 2015 more than a million migrants came to Europe from Africa and the Middle East, where the war in Syria was still going on. The so-called migration crisis was the event that woke up fears among many Europeans. Many interpretations of that crisis were created by political and medial subjects. One interpretation of the situation was that the European Union (EU) organizes this migration to Islamize Europe. This argument fits in the narrative concept of conspiracy theory.

The mentioned conspiracy theory is still widespread, and the objective of the paper is to analyze argumentation strategies of this conspiracy theory. These strategies legitimize reality constructed by this conspiracy theory and ascribe identities and characteristics to political and non-political

${ }^{1}$ Faculty of Arts, University of Ss. Cyril and Methodius in Trnava, Nám. J. Herdu č. 2, Trnava, Slovak Republik, Email: stefan.izak@ucm.sk. 
actors presented in the discourse. Strategy is "a more or less intentional plan of practices (including discursive practices) adopted to achieve a particular social, political, psychological or linguistic goal" (Reisigl - Wodak, 2009, p.94). In the next chapters it will be shown that conspiracy theories divide world into two antagonistic poles and consumers of conspiracy theories can see the world in this frame, so it is important to know how reality and its antagonistic poles are constructed by analyzed conspiracy theory.

The secondary objective of the paper is to find out binarities which this conspiracy theory works with. Binarities are a simple but important tool for readers to orientate in the discourse, and they explicitly create the image of the group's enemy by dividing reality into two antagonistic poles ("good" ones and "evil" ones). In that concrete case, the role of conspiracy theories in propaganda which has impact on public opinion is shown. Analysis of strategies and binarities will reveal how identities of concrete political and non-political actors are created. It will help understand the role of the enemy making and consolidating own identity in concrete political space. Following the paper's objectives, these researched questions are formulated:

- What kind of argumentation strategies are used to legitimize analyzed conspiracy discourse?

- What binarities analyzed conspiracy discourse work with?

- What identities and connotations are ascribed to actors represented by these binarities?

By research and analysis of researched material I try to prove validity or invalidity of the hypothesis that conspiracy theory is a useful genre for political propaganda, especially for current Eurosceptic ${ }^{2}$ parties which doubt official political system of the EU and its policies. I also suppose that argumentation strategies simplify reality and try to create a image of enemy from the EU, its institutions, representatives and migrants.

\footnotetext{
${ }^{2}$ Eurosceptic parties standing against current form of the EU's political system or against integration level of their country in the system. They want to reverse this level of integration or deconstruction of the EU's political system. Deconstruction may be partial, that is, a party may seek to return certain competences to the national level, to withdraw from certain areas (the eurozone, Shengen, etc.) or to abolish some EU's institution. Such parties can be characterized as soft Eurosceptics. Then there are parties that perceive the Union as totally unacceptable (hard Eurosceptics). These parties support their withdrawal from the EU or the dissolution of the Union (Baboš - Králiková - Villági, 2020).
} 
The research sample consists of three Slovak pro-Kremlin media ${ }^{3}$ Hlavné správy, Slobodný vysielač a Zem a Vek. ${ }^{4}$ Panczová claims that these sources present Russia and the West in binarity, Russia as the protector of traditional values against the decadent West. They use apocalyptical rhetoric and predict new conflicts (Panczová, 2017a). Mentioned media belong among the most popular alternative media in Slovakia, with the ability to address a wide range of the population. Hlavné správy have 55,290 followers on Facebook, Slobodný vysielač 80,923 and Zem a Vek 5,441. ${ }^{5}$ Primarily Hlavné správy can address almost the same amount of people on Facebook as many mainstream media, research of Facebook interactions shows (Struhárik, 2019).

These media had been monitored for two years, from December 2016 to October 2018, every second month in a year. I had been collecting news containing words migration, migrants, refugees, asylum seekers etc. in the title of the article but the news had to be about migration from Africa and the Middle East to Europe. For the text analysis, discourse analysis is used. By using this method it is possible to reveal concrete argumentation strategies and patterns by which texts are produced. According to Zuzana Panczová, the objective of discourse analysis is to analyze ways of argumentation which can justify some objectives (Panczová, 2017).

Given the theoretical framework of the paper (social constructivism), method of discourse analysis was a logical choice to make. Conspiracy theories are understood as a specific kind of discourses which construct a certain type of reality and a discourse analysis can help me reveal the rules and patterns on which reality is constructed. Identified argumentation strategies which create reality in a certain way can be also found in other similar conspiracy discourses and this paper should contribute to the discussion how in-group's and out group's idintities are created by this type of discourses. Advantage of discourse analysis is that discourse consider wide social and cultural context and therefore discourse strategies are

\footnotetext{
${ }^{3}$ In the paper pro-Kremlin media are understood as media which define themselves in opposition toward mainstream media and try to bring non-dominant and marginalized (alternative) discourses on important political and social events, phenomena and problems. These media are usually non-critical and positive toward current Russia politics and they share resistance towards a contemporary political system of the EU, liberal democracy and Western routing of Slovakia. They produce propaganda that is similar to official discourses of Russian state media.

${ }^{4}$ In English Hlavné správy (Main News), Slobodný vysielač (Free Broadcaster), Zem a Vek (Earth and Age).

${ }^{5}$ Data for 23.4.2020. Zem a Vek changed its Facebook page in February 2020. This is the reason why they have fewer followers. In December 2019 they had 34,959 followers.
} 
relevant for the way of reproducing and legitimizing of the knowledge in concrete cultural context.

The analysis is focused especially on the strategies of exclusion and inclusion which justify belonging to in-group and out-group. The first step in the analysis was to identify articles where analyzed conspiracy theory was present. The basic unit of the analysis was an article. I tried to reveal which actors are presented in articles, how they are named, presented (positively, negatively, by stereotypes, labels, metaphors etc.) and who has an opportunity to speak. The identification of their actions and interests was important, too. Another step was to identify relationships among actors, if actors and their interests were consistent or in the opposition to other actors presented in the article. For that purposes, the lexical side of the texts and identification of verbs, nouns, adjectives, etc., connected to actors and expressing their interests, was examined. Connotations of these words were important because these words help create identities of actors, their position and interests. Chosen words, sentences, articles and relations among them created arguments and showed argumentation strategies by which conspiracy discourse was legitimized. Analyzed strategies were present in many articles and sentences. Parts of the texts that point to the studied strategies the best are selected and analyzed in the empirical part of the paper.

\section{CONSPIRACY THEORIES}

Understanding of conspiracy theories is in this paper embedded in Peter Berger and Thomas Luckmann's theory of social constructions of reality. They say that social reality is socially created within the community. This means that every community constructs and explains meanings assigned to phenomena, objects, persons, etc. in its own way. It creates its own symbolic world that legitimizes the social structure and the existence of institutions. Each community creates its own reality, which is served to new members of the community during socialization. Knowledge is made up by people whose manifestations are determined by this knowledge (Berger - Luckmann, 1999). Discourses are tools of this construction of reality. Discourse is "a systematic knowledge articulation naturalizing the social power of its originators through the naturalization of knowledge that gives legitimacy to power" (Bočák, 2012, p.4). Discourse can be understood as a filter of knowledge, that says what is acceptable, normal, what is preferred and what is marginalized. Discourses offer various interpretation of reality, 
but they are not stable, they are dynamic and can be modified. For Patrick De Vos, discourse is the people's method for understanding and interpretation of social reality, which is constructed by discourses and, on the other hand, influences the form of these discourses (De Vos, 2003). Texts are parts of discourses. In texts we can find traces of ideological fights for dominance and hegemony of certain type of reality. Discourses are tools for legitimation and delegitimation of power (Reisigl - Wodak, 2009).

Conspiracy theory is "Unsubstantiated, unverified, officially unaccepted information that warns of a dangerous conspiracy. In connection with important historical events, they emphasize the role of conspiracy (or conspiracies) and do not believe in official justifications. The actors of these conspiracies may be members of minorities, various representatives of the category "foreign," representatives of social elites, or nameless members of the state apparatus ("system")" (Panczová, 2017, p.14). Based on Berger and Luckmann's theory, we can understand conspiracy theories as discursive constructions of knowledge, based on the binary oppositions, where one group conspires against the other. Serge Moscovici writes that conspiracy theories use antagonism to divide people into two groups. They create a simplified black and white reality where one pure, normal, good group, and other impure, abnormal, evil group fight each other until the final victory (Moscovici, 1987).

Other researchers agree that the key sign of conspiracy theories is the construction of threats by using already existing stereotypes, prejudices, and images of external or internal enemies. Veronique Campion-Vincent writes that conspiracy theories create the image of an enemy who wants to harm a particular group. By this creation of a threat, conspiracy theories help to strengthen the group's identity against the enemy; therefore, they are often connected to nationalism. (Vincent-Campion, 2005). Panczová agrees that conspiracy theories are tools of the social antagonism and demonization of some groups. Conspirators in conspiracy theories do not attack only the ingroup's safety, but they attack fundamental values like family, health, morality, that is the reason why these (outside) conspirators are dangerous (Panczová, 2011). Binarities are a characteristic sign in construction of all social identities and it is not just a matter of conspiracy theories. There is a widely known theory of social identity presented by Henri Tajfel and John Turner who says that identifying with a particular social group offers people a place in society, showing where they belong and thus showing who they are and are not. The evaluation of an own group depends largely on the evaluation and differentiation from other groups. Individuals try to evaluate 
their own group more positively than other groups because they want to achieve a positively evaluated social identity (Tajfel - Turner, 2004).

Jan-Willem van Prooijen and Mark van Vugt suggest that powerful political groups and minorities figure as enemies in the majority of conspiracy theories (van Prooijen - van Vugt, 2018). Although in the last years, we can observe the trend that the danger is slowly removing from minorities to elites and elites are more and more accused of conspiracies against ordinary people (Vincent-Campion, 2005).

According to van Prooijen and van Vugt, conspiracy theories have five basic signs. The first is a pattern. Conspiracy theories make an assumption of how people, objects, or events are causally interconnected. They create a world without accidents, a world where events can be explained by linear causality. The second is an agency. Conspiracy theories ascribe intentionality to the actions of conspirators. The third is a coalition. There is never just one person involved in the conspiracy; there is always a coalition of actors. The fourth is a threat. The goals of conspirators are always harmful, never benevolent. The fifth is secrecy. Conspirators always act in secrecy (van Prooijen - van Vugt, 2018). Towards these signs, I can add a general narrative pattern of conspiracy theories which is formed by three steps. The first is the presentation of the negative image of the present and near future. The second is revealing the causes of this state (image of an enemy, enemy's crimes, tools, and cooperators). The third is an appeal to resistance and fight against the enemy (Panczová, 2017).

If the premise that conspiracy theories create a threat of some minorities and elites is accepted, we can assume that people who interpret reality by conspiracy theories or are exposed to conspiracy theories have negative and the stereotypical perception of these groups. Daniel Jolley, Rose Meleady, and Karen M. Douglas examined tendencies to the discrimination in people who were exposed to conspiracy theories. They found out that exposure to conspiracy theories regarding one outside group (Jews) increased not only prejudices towards this group but increased discrimination and prejudices also towards other uninvolved outgroups (Jolley - Meleady - Douglas, 2019). If the fact that conspiracy theories doubt elites, official institutions (represented by these elites), the official interpretation of events, etc. is considered, it is logical that conspiracy theories can have an enormous political impact and they can be part of the populist ${ }^{6}$ political argumentation

${ }^{6}$ Populism is "an ideology that considers society to be ultimately separated into two homogeneous and antagonistic groups, "the pure people" versus "the corrupt elite", and which argues that politics should be an expression of the volonté générale (general will) of the people 
to reach power goals. That is why conspiracy discourses are in democratic states usually part of far-right or far-left populist parties communication. Doubting current official institutions and a system is a crucial point in their political agenda. Mark Fenster says that conspiracy theories can expose inequities of a political, economic and social order. Conspiracy theories help unite individuals in one homogenous category "the people" against homogenous category "other" represented by a power bloc. That is why conspiracy theories are disseminated on a political level mainly by populists (Fenster, 2008).

The relevance of the hypothesis that conspiracy theories are a crucial communication part of far-right and far-left populist parties is confirmed by the research of Robert Klobucký. He observed that people who believe in the concrete conspiracy theory (reality is usually different from an official institution claim, and the world is ruled by powerful secret groups) are less interested in participation in the public life because they do not believe that they can change something. Conspiracy explanation of reality usually downplays the possibility of influencing major events by the free expression of people. People who use conspiracy theories incline to prefering alternative political regimes that should guarantee higher-order, equality and social justice while limitation of some freedoms would not be a big loose for them (Klobucký, 2015).

\section{PROPAGANDA}

From the information mentioned in the previous chapter, it is evident that conspiracy theories can be a very effective discursive tool in a political propaganda. Propaganda also uses a simplified "good vs. bad" perspective to divide people into two antagonistic camps and works with the image of the enemy, which serves as the mobilizing factor for the ingroup's identity (Alvarová, 2017).

In the paper, propaganda is understood as "the deliberate, systematic attempt to shape perceptions, manipulate cognitions, and direct behavior to achieve a response that furthers the desired intent of the propagandist" (Jowett - O’Donnell, 2012, p. 7). Ladislav Bittman says that successful propaganda must exploit the opponent's weaknesses and prejudices of people. This is the reason why propaganda uses a language and arguments which are

(Mudde, 2004, p. 543). Populists proclaim themselves as representatives of the "pure people" and take on the role of fighters against the "corrupt elite". Populism can easily be combined with other ideologies, left-wing, right-wing, conservative or liberal etc. (Mudde, 2004). 
consistent with people's beliefs. Propaganda tries to persuade people that the external or the internal enemy is responsible for their problems. (Bittman, 2000). The basic emotion propaganda works with is fear, that is why propaganda is built on the people's fears (of foreigners, Muslims, Jews, secret groups, elites, etc.) (Alvarová, 2017).

If we look at the state pro-Kremlin propaganda, its primary objective is to disintegrate the West (in our case the EU) by using its own problems to increase the influence of Russia in Europe (Pomerantsev - Weiss, 2014). The migration crisis could be regarded as one of these problems, because it brings many challenges the EU has to deal with, and it wakes up fear of the externalenemy in the people's perception. Therefore, migration as a topic is used in the conflict of discourses among different political subjects. Vera Tydlitátova claims that the migration crisis became a sort of medial shield and a tool of the state pro-Kremlin propaganda, through which Eurosceptic narratives were spread (Tydlitátová, 2017).

Alternative media Hlavné správy, Slobodný vysielač, Zem a Vek produce content in line with the content of official Russian channels like RT or Sputnik, not only in the theme of migration and the EU's migration policy. They regularly use Russian sources and spread Kremlin discourses about the decadent, unfair, dictatorial EU, which falls apart under pressure of migrants and where life is very dangerous. Migration discourses are in these media interconnected with criticism of the EU, nationalist, populist, and Eurosceptic narratives and with praising of pro-Kremlin politicians (Ižák, 2019). Researches of Rashid Gabdulhakov (2016) and Lyubov Cibulska (2018) confirm that Russian state media produce the same kind of discourses as mentioned Slovak alternative media and that the goal of these discourses is to relativize trust in the EU.

Similar studies as I do already have been carried out. The topic of conspiracy theories in Russian political and medial discourse is the basic research topic in the book Fortress Russia: Conspiracy Theories in the PostSoviet World (2018). Its author Ilya Yablokov argues that since the mid 2000 's anti-Western conspiracy theories have moved to the centre of an official political discourse of Russia. The West became the conspiring "other" and this discourse is regularly used by political elites and Kremlin media. An important role in the Russian efforts to spread its vision of global affairs is played by far-right and far-left organizations with ties to Kremlin (Yablokov, 2018). Yablokov's research of conspiracy theories in Russian state television RT has shown that anti-Western conspiracy theories play an important role in RT's production. These theories aimed at uniting global 
community of "the people" against the dangerous "other" represented by the West (Yablokov, 2015).

Similar research was conducted by Kohei Watanabe who was collecting news from another Russian state agency Sputnik. Watanabe came to the conclusion that Sputnik promotes skepticism towards Western institutions. Conspiracy theories as a part of propaganda can be a very effective tool for disseminating anti-establishment narratives advancing populist parties in the West (Watanabe, 2018).

\section{ANALYTICAL PART}

"The European Union has betrayed European civilization by organizing the flooding of our states by migrants" (Zem a Vek, 2018). In a simplified way, this is an analyzed conspiracy theory. The structure of the line is simple. On the one side, there is a group we (our states) which is victim of a group they (the EU, migrants). The group they tries to harm the group we by organizing migration. The verb "organizing" expresses intention in the Union's action. In this concrete sentence the author uses the word with a negative connotation "betrayed" to describe the EU's policy. The author evaluates (negatively) this migration policy by this verb and justifies a negative attitude towards the Union. A natural metaphor "flooding" is used to homogenize migrants into one flood. This conspiracy theory is understood as a discursive frame of reality that uses the topic of migration to present and spread a concrete political message through the examined media. An attention is paid especially to strategies of exclusion and strategies of dividing reality into two antagonistic camps.

This conspiracy theory is the most complex conspiracy theory about the migration crisis which occurred in these media during my two year's research. Examined media publish news taken from mainstream Slovak and foreign media and news agencies. They take news mostly from The News Agency of the Slovak Republic (TASR). The second part of their sources is made of other pro-Kremlin media, Russian state media (Sputnik, RusVesna, RT, etc.) and they publish their own author's news. The conspiracy theory was present only in the news not taken from mainstream media and news agencies. In 91 of 490 news $(18,6 \%)$.

The basic argumentation strategy of conspiracy theory says that the objective of the EU is to use migration for the civilization change in Europe: "The European Council does not aim to close African migration flood in Libyan logistic corridor. It would resist its long-term agenda to change 
the demographic composition of the Old continent into multi-racial and multinational" (Sloboda, 2017). The fundamental idea of this theory is the protection of the Slovak nation (European nations and Christian civilization in a broader sense) against external and internal enemies like migrants, the EU, politicians, etc. This citation says that migration is not an accident, it is a part of the bigger plan of the Union ("long-term agenda"). Intentionality is expressed (agency - second sign of conspiracy theories). The aim of the European Council is dangerous for European nations, because it should change composition of European nations and mix them with African migrants.

A typical sign of conspiracy theories coalition (of conspirators) is visible in the analyzed theory, too. The EU cooperates with NGOs and foundations on the demographic change in Europe: "[Migrants: Author's note] Are mostly Muslim faith and they refuse to assimilate. The politically hyper-correct European Union in connection with foundations and NGOs gradually push Europeans to assimilate under the cloak of multicultural enrichment of the majority population" (Sloboda, 2017a). It is important to show that migrants are different because different out-group represents potentional threat to in-group. The first sentence implies that they have different culture and "refuse to assimilate" (generalization is used), so it makes the boundary between them and us and shows that they have no interest in being part of our (European) society. In the last part of the quote, the irony is used ("multicultural enrichment") and the author shows that the Union prefers migrant's culture over the European one because it forces "Europeans to assimilate" which also implies that there are more Muslim migrants than Europeans. Media are part of this conspiracy, too. They do not bring the truth because they are sold: "And, of course, sold media is completely silent about it, publish nothing to make people think that the migration wave has stopped and the migration crisis is over" (Bago, 2016). This conspiracy theory also doubts media and NGOs. According to pro-Kremlin media mainstream media manipulate public opinion because they did not refer about migration. This interpretation should delegitimize mainstream media and strengthen relevance of pro-Kremlin media.

Danger, as a result of the EU's migration policy, is emphasized by news about criminality, Islamization, ethnic conflicts, and other problems related to migration to the Western European countries. The lousy situation in these countries is used as a warning for countries like Slovakia: "Western Europe has reached supposed critical saturation of Muslims, which allows violent destabilization of society and later, after disruption, taking power over 
its ruins" (Hlavné správy, 2018). By this kind of message media construct reality where migration and the EU's migration policy are existential threats to the whole Western civilization and the European way of life as we know it. The objective of migrants should be a violent assumption of power in Europe. Islamic faith of migrants is explicitly expressed in many articles. Aim of this strategy is to show another difference between mainly Christian Europeans and mainly Islamic migrants. This citation presents Europe as a physical space with limits for people of different faith. This space cannot be saturated by these people because it is in danger of destabilization.

Concrete politicians are mentioned as a part of this conspiracy theory, too. Migration is often connected to politics of the German chancellor Angela Merkel (who accepted more than a million migrants in Germany) and the French president Emmanuel Macron "Such a gesture [Accepting Syrian orphans: Author's note] will not satisfy either Merkel or Macron or NGOs, whose multicultural policy mixes a deadly cocktail for the peculiar culture of European nations and Christian civilization on our continent. Mass migration is not and has never been beneficial. It came as a result of the failure of a dominant culture unable to prevent natural but especially war cataclysm and has always been the cause of the disintegration of states, the demise of nations, and whole civilizations. This was true of the culture of the Sumerians, the ancient Maya, of Egyptian and Roman civilization" (Števko, 2018). Migration is often connected with words of negative connotations like death, failure, war, disintegration, etc., to make people associate words like migration, multiculturalism negatively. This quote shows us that analyzed media try to persuade people about the negative impacts of migration by using historical analogy with disintegration of ancient civilization. Analyzed media often use the first person of the plural to show that they stay with group we and to show unity of ingroup. In this case, the author uses the term "mass migration" to express that migration is still going on on a large scale. Mentioning of concrete name of politicians should point out on responsibility of them. Uniqueness of "European nations and Christian civilization" is expressed by adjective "peculiar", it should show that European civilization is worth to protect.

Another historical analogy is present in the next quote: "But Slovakia did not fight for a thousand years for its independence and sovereignty to hand it over to the West for a change..." (Hlavné správy, 2018a). Historical Slovak fight for independence and sovereignty during times when Slovakia was part of the Kingdom of Hungary, Habsburg's monarchy, Austria-Hungary, is compared with present days when Slovakia is part of the EU. This sentence 
implicitly says that the Union and the Western structures are not guarantors of the Slovak "independence and sovereignty". Narrative of historical fights for freedom is typical for construction of the nation's positive image.

One of argumentation strategy says that the current migration is just a part of the long process we can observe. The EU has started this process more than 20 years ago, and the goal is to destroy all identities in Europe and create new mixed people: "And in the last 20 years, the European elites have convinced themselves that the right way to develop Europe is to dispose our self-identity... Those who are more interested in politics know that the "map" of Paneurope was not painted by the Slovak Prime Minister or his foreign guests, but almost a hundred years ago, a native of Tokyo CoudenhoveKalergi - himself a blend of Japanese and "European" - and circles behind standing. This "map of Europe" was brown. Full of people - neither white nor black, but brown, mixed on purpose, easy to control, without roots, family, national, social, religious people without a compass" (Mohorita, 2017). This argument is supported by mentioning conspiracy theory about the concept of "PanEurope" drawn by Coudenhove-Kalergi (Kalergi's plan). By using this current argument, the situation might seem like a logical result of a specific plan. Notable in that text is implying that mixed people are easy to control because they do not have a "compass" (roots, national, religious, social identity). Another important part is using the sentence: "Those who are more interested in politics know that the "map" of PanEurope" which imply that some people can see behind the scene (others do not) and know about the plan. In the first sentence of this part we can see a typical populist rhetoric presenting evil plans of the political elite.

Activities of Goerge Soros should be proof that migration is organized. He is characterized as: "The controversial billionaire known for advocating boundless liberalism, promoting LGBTI, gender ideology, controlling politicians and financing coups" (Eurosprávy, 2017). He is accused of financing the migration crisis to change Europe: "In September 2016, George Soros donated \$500 million to the European and US refugee crises and refused to clarify where and how the money will be used. One note in the Soros Foundation's documents (revealed by DCLeaks in August 2016) statesthat a European immigration issue should be accepted as a "new standard" and the crisis opens "new opportunities" to influence immigration policy on a global scale. This suggests that NGOs have at least indirect participation in projects that destroy the EU's social stability, just as they did in Ukraine (2014) and many times before in other places. It is difficult to dispel the impression that the full weight of the refugee phenomenon, together with the NATO and social 
wars within the countries, is part of a much larger and more ominous plan of secret elite" (Strážan, 2017). The last sentences show us that analyzed media understand and present many events as a result of the conspiracy, where an active role is played by Soros. Thus, migration is just one of the events (caused by conspiracy) which should change the face of Europe according to Soros's plans. A frequent argument is also pointing out some unspecified larger plan of a secret elite (secrecy - typical sign of conspiracy theories). Soros personifies a typical enemy in conspiracy theories. He is presented as a mysterious person with a massive influence on the political scenes around the world, he finances "refugee phenomenon, social wars" from behind. The situation in the EU is compared to the revolution in Ukraine in 2014. The analyzed media share pro-Kremlin view on this revolution and present it as a conspiracy of the West, NGOs and local authorities. NGOs and Soros are explicitly accused of a planned destruction of "the EU's social stability".

Another strategy combines migration with other topics and dangerous conspiracies organized by the Union. In the next case, it is a conspiracy theory that the Union forces LGBTI ideology to its Member States: "It should be mentioned that, 15 years ago, the EU started to push LGBTI ideology into the law systems of individual EU Member States, also through NGOs and Soros. We know very well what this agenda brings. Homosexuals cannot create life. This is also one of the aims of this agenda to reduce the population of the Christian white population. (Another aspect of this effort is to create living conditions that do not allow young people to start a family). The next step which should replace this decline of the white population is the admission of Muslim migrants, who will reduce the proportion of the Christian population in Europe" (Harabin, 2017). In this quote connection between organized migration and forced LGBTI ideology is present. The topic of LGBTI is added to analyzed conspiracy theories to make it more complex and to point out that the real goal of the EU is the replacement of the Christian white population by Muslim migrants. Linear causality and simplification is explicit in this sequence. Author tries to find connection between migration, LGBTI community, Soros and the Union and tries to explan it by his subjective attitude. LGBTI ideology serves as a tool to reduce the European population and migrants as a replacement. In this context LGBTI community is similar threat to Christian civilization in Europe as migrants. Hlavné správy quoted the Slovak right-wing, populist politician Štefan Harabin who was a candidate in the Slovak presidential elections in 2019 and the election's leader of the party Motherland in parliamentary elections in 2020. Frequent quoting and giving uncritical space for populist right-wing or left-wing politicians 
are a typical feature of analyzed media occurring during the whole time of monitoring.

In the previous parts, I analyzed quotes, where actors of conspiracy were clear (the EU, NGOs, Soros, media), but conspiracy theory creates a reality where migration is organized by the secret elites. This message is visible in the article titled: "Refugee's invasion is a geopolitical tool of global elites to blackmail Europe" (Bednár, 2018). The second word ("invasion") suggests that migration is organized and dangerous. The word invasion implies a battle or war and has negative connotations. This combat terminology is frequently used to raise fear among readers and put antagonistic groups into the hostile relationship. We can see that this title works with unconcreted word's connection to "global elites". It implies that somebody tries to influence politics from behind (instead of politicians) and "blackmail Europe". The article continues: "In essence, strong migration waves are artificially induced by someone who wants to achieve military, political, and economic goals at the expense of the state or states to which they have directed. Migration waves are very effective and act very fast". Migrants are presented as an effective tool of unspecified "someone" to achieve certain goals. Obscurity is emphasized by the used passive voice. Importance and danger of migration is expressed by adjective "strong". Migration is not understood as something natural but "artificial". This understanding understates humanitarian aspects of the current migration.

European politicians are presented as weak, so other global institutions are marked as organizers of migration. Migration is presented as a part of the global plan organized by the United Nations (UN) in this case: "In recent years, we have seen a tremendous effort to flood Europe with more and more migrants, and especially the eastern part, but Juncker and Merkel were weak for that. Moreover, it can be conspired that the one who is so rushing to swap the European population has decided to use greater tools when smaller is not enough. Use the corruption corps of automatic voting puppets who represent individual puppet governments all over the world at the UN to adopt a document under the head of the largest available authority, the authority of the global UN, aimed at legalizing a new human right, the right to migration" (Lehotský, 2018). This part is from the article about Marrakech Migration Pact presented by the UN. This pact is in analyzed media presented as a legitimation of illegal migration. Representations and governments of states in the UN are marked as "puppets" of (mysterious) "one who is rushing to swap the European population". By the words like "puppets", "corruption corps" the author tries to suggest that politicians cannot make their own 
decisions and do it just because of money, not for people. Not only the EU but also other international institutions (the UN) are presented as a part of this conspiracy theory. Migration is presented by a natural metaphor flood (which homogenizes migrants in the one monolithic group) and the argument may raise fear among the Slovak population that this flood should target, "especially the eastern part" (of the Union). Migration pact is presented as a small piece in this conspiracy of politicians against ordinary people (typical populist rhetoric).

A common strategy is to put Slovak non-populist politicians as participants in this conspiracy theory: "Everything begins to fit together. While the government rejects mandatory quotas, it seems that the government thinks about voluntary admission of migrants. Prime Minister Pellegrini even calls for migration as a result of the "labor shortage in Slovakia," and at the same time, it would also fulfill our obligations under the Marrakesh Declaration" (Gdovin, 2018). The Slovak Prime Minister should participate in this conspiracy despite the government's statement about not accepting migrants. The author uses Pellegrini's words about the "labor shortage" as an argument supporting this conspiracy theory and as a proof of his hypocrisy. This strategy serves to the delegitimation of domestic politicians. The phrase "everything begins to fit together" is used to confirm causality between activities expressed in argument.

Another strategy points out that the migration crisis is the large economic business and elites earn money from it: "There is a large asylum industry in Germany, which criminally makes a hundred million euros of the refugee crisis. The industry has established itself perfectly and is expanding without obstacles as a malignant tumor" (Bednár, 2018a). The asylum industry is compared to a tumor. It is understood as something dangerous which can spread around organism (Europe) and kill it. Migration is understood as an opportunity to raise money. Asylum process is called "industry" to demonstrate that migration is just another kind of business. This strategy relativizes humanitarian aspects of migration.

One of the narrative elements of conspiracy theories is a challenge on defense against conspirators. By articulating the challenge, the media try to present hope of the final victory and show to readers who is a warrior against conspirators and who protect the interests of ordinary people. The next quote says that countries are starting to turn against current status quo which is according to this quote in favor of migrants: "Despite statements by the Brussels elites on the need to make mass migration to Europe the norm and on the need to change the mindset of Europeans in favor of migration, EU 
countries are gradually starting to move away from generous asylum policy" (Hanzlíková, 2017). According to this quote, "changing the mindset of Europeans" is an important part of the whole conspiracy against Europeans and it shows us the extent of the conspiracy. The Union is understood as an organization which uses operations to change people's mind what is typical for authoritarian regimes. An important point in this citation is that the European countries move away from the EU's migration policy which is described as "generous". The adjective generous says that this policy is in favor of migrants. The attitude of European countries against migration policy of the Union should show that they stand in the opposite pole to the "Brussels elites". Pro-Kremlin media often use metonymies like "Brussels elites" to support thesis about a centralized character of the EU and its elitism. Part of these operations are not only changing of people's mind in favor of migration but delegitimation of the EU's critics: "Those who warned about plans for mass relocation from Asia and Africa to Europe just a few months ago were given the label of deluded victims of fantasy conspiracy theories" (Sloboda, 2018). This quote should justify critics of organized migration as people who tell the truth and because of this truth they become victims of repressive actions. Analyzed conspiracy theory works with the argument that people in Europe live in authoritarian systems where the truth about migration is forbidden to say, what is the proof of the existing conspiracy.

Using public opinion as an argument against migration or the EU is present in the analyzed conspiracy theory. Link to public opinion should legitimize binarity of "good" us and "bad" them. Public opinion's argument serves as a proof that people are against plans of elites who organize migration, so these plans are illegitimate: "The people of Saxony, like Poles and Hungarians, resist the inexorable Islamization of their country, which is pushed by all possible and impossible political means and pressures from Brussels and Berlin" (Hlavné správy, 2018a). Nations of the V4 group are often mentioned as positive examples of a real protection of national interests in contrast with the Western European countries. Using contrast as an argumentation strategy is common in the analyzed conspiracy theory. By mentioning the capitals of Germany and the Union the author shows who is responsible for organization of migration. Important is term "their country" which implies that countries belong to people living in those countries. Only they should have the right to make decisions about the country. The analyzed media sometimes add challenges to rise against politicians and elites: "Europeans - we all who stand for sovereignty of our nations, but also for our traditional Europe, which helps those who really deserve it - let us defend ourselves 
against those who shamelessly sell us!" (Bednár, 2018b). The entire quote is put in binarity between one group which wants to protect "sovereignty of our nations, traditional Europe" (positive attitude) and another group which does not share these ideas (negative attitude). The EU is meant to be in the second group. The author uses the first person of plural (our, ourselves, us) to unite in-group and to show that he is also part of this group.

The answer to the question who are the politicians able to protect European nations against migration could be found in many articles where media write about them positively or sometimes subjectively evaluate and portray them as saviors of Europe: "That is also why I fully support both politicians [Orban, Salvini: Author's note] in their steps because they are one of the few European politicians who are really serious about fighting illegal migration and saving today's Europe of nation-states. Furthermore, they deserve compliments and thanks. Both of them are indirectly fighting for us with Brussels, the Western oligarchs, the NGOs and various predecessors, and the sun-people" (Bago, 2018). Both mentioned politicians represent Euroseptic, populist, right-wing ideas and they legitimize Kremlin politics. Support of Salvini and Orban is justified by a moral appeal on "saving today's Europe of nation-states", what could be done by "fighting illegal migration" like Salvini and Orban do. Migration is understood as a danger to European nation-states and politicians are responsible for their saving. These politicians have to fight also against the EU (metonymy "Brussels"), "the Western oligarchs, the NGOs...". All these actors represent a danger for European nation-states. By using the first person of plural the author identifies in-group with nation-states against the Union and other actors.

\section{CONCLUSION}

The basic objective of this paper was to identify argumentation strategies of a conspiracy theory the European Union organizes migration to Islamize Europe. These strategies constructed the image of an enemy who wants to destroy European nations and civilization. The rightness of concrete political parties and politicians was underthrusted by the analyzed conspiracy theory. The reality is based on binarities Migrants vs. Europeans, Ordinary people vs. Politicians and the EU, Right-wing populist politicians vs. other politicians and the EU. The second objective of this paper was to identify these binarities, because one of the most crucial characteristics of propaganda and conspiracy theories is creating an enemy. This enemy is constructed by dividing society into two antagonistic groups, where 
the group we is threatened by the group they. In this case, the group we is represented by Europeans, ordinary people whose interests are protected by Eurosceptic, right-wing politicians and the group they is represented by migrants who are a tool in the plan of the EU, other politicians and their cooperators (media, NGOs etc.) to Islamize Europe. Just like others, this conspiracy theory is not politically neutral; it spreads concrete political messages praising populist right-wing political figures and delegitimates all others. My research shows us that conspiracy theory is a useful tool for a political propaganda because it can simplify reality and serve the image of the enemy to mobilize people against it. In pro-Kremlin propaganda spread by analyzed media a conspiracy theory is used to create an image of the "evil" West what is also the goal of pro-Kremlin propaganda disseminated by official political and medial discourses in Russia.

\section{REFERENCES}

ALVAROVÁ, A. (2017). Prúmysl lží. Propaganda, konspirace a dezinformační válka. Praha: Triton, 2017, 256 pp.

BABOŠ, P., KRÁLIKOVÁ, M., VILLÁGI, A. (2020). Stranícky euroskepticizmus pred vol'bami 2020. Bratislava: Univerzita Komenského, 2020.

BAGO, M. (2016). Dôkazy, že mimovládky s vedomím politikov pašujú migrantov do Európy. In: Zem a Vek. [online]. Available at: <http:// zemavek.sk/articles/view/dokazy-ze-mimovladky-s-vedomimpolitikov-pasuju-migrantov-do-europy>. [Accessed 16.12.2016].

BAGO, M. (2018). Salvini a Orbán na spoločnom stretnutí avizovali vznik celoeurópskej protimigračnej aliancie. In: Zem a Vek. [online]. Available at: $\quad<$ https://zemavek.sk/salvini-a-orban-na-spolocnom-stretnutiavizovali-vznik-celoeuropskej-protimigracnej-aliancie/>. [Accessed 31.8.2018].

BEDNÁR, R. (2018). Invázia utečencov je geopolitický prostriedokglobálnych elítna vydieranie Európy.In: Hlavnésprávy. [online]. Availableat: <https:// www.hlavnespravy.sk/invazia-utecencov-je-geopoliticky-prostriedokglobalnych-elit-na-vydieranie-europy/1498384>. [Accessed 22.8.2018].

BEDNÁR, R. (2018a). Kriminálne špinavé metódy zarábania: Azylový priemysel v EÚ. In: Hlavné správy. [online]. Available at: <https:// www.hlavnespravy.sk/kriminalne-spinave-metody-zarabania-azylovypriemysel-v-eu/1490000>. [Accessed 12.8.2018].

BEDNÁR, R. (2018b). V Nemecku vysokí štátni úradníci utečencom predávajú azyl. In: Hlavné správy. [online]. Available at: <https:// 
www.hlavnespravy.sk/v-nemecku-vysoki-statni-uradnici-utecencompredavaju-azyl/1380616>. [Accessed 21.4.2018].

BERGER, P. L., LUCKMANN, T. (1999). Sociální konstrukce reality. Pojednání o sociologii vědění. Brno: Centrum pro studium demokracie a kultury, 1999, $214 \mathrm{pp}$.

BITTMAN, L. (2000). Mezinárodní dezinformace. Černá propaganda, aktivní opatření a tajné akce. Praha: Mladá fronta, 2000, 360 pp.

BOČÁK, M. (2012). Diskurz - koncept kritický: nereflektované riziká používania výrazu mediálny diskurz. In: Jazyk a Kultúra. Vol. 3, No. 10, 2012.

CAMPION-VINCENT, V. (2005). From Evil Others to Evil Elites. A Dominant Rumor Pattern in Conspiracy Theories. In: FINE, G. A., CAMPIONVINCENT, V., HEATH, CH. (ed.). Rumor Mills. The Social Impact of Rumor an Legend. Piscataway NJ: Transaction-Aldine, 2005, pp.103-122.

CIBULSKA, L., KAVATSJUK, R., MAKUCHIN, O., POPOVIČ, N. (2018). Image of European Countries on Russian TV. Kyjev: UCMC, ECEP, 2018, 46 pp.

DE VOS, P. (2003). Discourse Theory and Study of Ideological Transformations: Analysing Social Democratic Revisionism. In: Pragmatics. Vol. 13, No. 1, 2003, pp. 164-180.

DOUGLAS, K. M., JOLLEY, D., MELEADY, R. (2019). Exposure to Intergroup Conspiracy Theories Promotes Prejudice which Spreads Across Groups. In: British Journal of Psychology. Vol. 111, No. 1, 2019, pp. 17-35.

Eurozprávy. (2017). George Soros zavelil: Európa postaraj sa o migrantov, obmedz fondy pre krajiny, ktoré ich odmietajú a Británia sa musí vrátit' do EÚ. In: Hlavné správy. [online]. Available at: <http://www. hlavnespravy.sk/george-soros-zavelil-europa-postaraj-sa-o-imigrantovobmedz-fondy-pre-krajiny-ktore-ich-odmietaju-britania-sa-musi-vratiteu/1025046>. [Accessed 3.6.2017].

FENSTER, M. (2008). Conspiracy Theories: Secrecy and Power in American Culture. Minneapolis: University of Minnesota Press, 2008. pp. 384.

GABDULHAKOV, R. (2016). Russian Discourses on Syrian Refugees in Europe and Central Asian Labour Migrants: Russia for Russian, Europe for...? Bishkek. Central Asia policy briefs, 2016, 32 pp.

GDOVIN, S. (2018). Ako premiér Pellegrini zavádza o Marakéšskej deklarácii. In: Hlavné správy. [online]. Available at: <https://www.hlavnespravy.sk/ ako-premier-pellegrini-zavadza-o-marakesskej-deklaracii/1421596>. [Accessed 3.6.2018].

HANZLÍKOVÁ, K. (2017). Napriek snahám urobit' z masovej migrácie normu aj Dánsko mení svoju pozíciu k migrantom. In: Hlavné správy. 
[online]. Available at: <https://www.hlavnespravy.sk/napriek-snahamurobit-z-masovej-migracie-normu-aj-dansko-meni-svoju-poziciumigrantom/1250460>. [Accessed 21.12.2017].

HARABIN, Š. (2017). Harabin rozobral zmluvy s EÚ. Žiadna povinnost' prijímat' migrantov tam nie je. Hrozí však, že vládny predstavitelia nejaký nový dodatok, ktorý túto povinnost' uložil, podpíšu. In: Hlavné správy. [online]. Available at: <http://www.hlavnespravy.sk/harabinrozobral-zmluvy-s-eu-ziadna-povinnost-prijimat-migrantov-tam-nie-jehrozi-vsak-ze-vladny-predstavitelia-nejaky-novy-dodatok-ktory-tutopovinnost-ulozil-podpisu/1228258>. [Accessed 4.12.2017].

Hlavné správy. (2018). Kedy sa moslimovia v Európe vzbúria? In: Hlavné správy. [online]. Available at: <https://www.hlavnespravy.sk/kedy-samoslimovia-v-europe-vzburia/1443052>. [Accessed 25.6.2018].

Hlavné správy. (2018a). SPD chce islamizáciu Saska cez nový integračný zákon. A čo Progresívne Slovensko? In: Hlavné správy. [online]. Available at: <https://www.hlavnespravy.sk/spd-chce-islamizaciu-saska-ceznovy-integracny-zakon-co-progresivne-slovensko/1326668>. [Accessed 27.2.2018].

IŽÁK, Š. (2019). (Ab)using the Topic of Migration by Pro-Kremlin Propaganda: Case Study Slovakia. In: Journal of Comparative Politics. Vol. 12, No. 1, 2019, pp. 53-71.

JOWETT, S. G., O'DONNELL, V. (2012). Propaganda and Persuasion. London: SAGE, 2012, $396 \mathrm{pp}$.

KLOBUCKÝ, R. (2015). Konšpiračné vysvetlenia a geopolitické preferencie: výskumná správa. Bratislava: Sociologický ústav SAV, 2015, 3 pp.

LEHOTSKÝ, I. (2018). Marakéšsky globálny komplot o migrácii: Svinstvo globálnych rozmerov v priamom prenose? In: Hlavné správy. [online]. Available at: <https://www.hlavnespravy.sk/marrakessky-globalnykomplot-o-migracii-svinstvo-globalnych-rozmerov-v-priamomprenose/1551966>. [Accessed 16.10.2018].

MOHORITA, V. (2017). Afričania a Aziati sa hrnú na Ukrajinu, aby sa odtial vd’aka zrušeným vízam dostali do EÚ. Na rane sú Slovensko, Pol'sko, Madarsko. In: Hlavné správy. [online]. Available at: <http://www. hlavnespravy.sk/africania-aziati-sa-hrnu-na-ukrajinu-aby-sa-odtialvdaka-zrusenym-vizam-dostali-eu-na-rane-su-slovensko-polskomadarsko/1095058>. [Accessed 8.8.2017].

MOSCOVICI, S. (1987). Conspiracy Mentality. In: GRAUMANN, C. F., MOSCOVICI, S. (ed.). Changing Conceptions of Conspiracy. New York: Springer-Verlag, 1987, pp. 151-169. 
MUDD, C. (2004). The Populist Zeitgeist. In: Government and Opposition. Vol. 39, No. 4, 2004, pp. 541-563.

PANCZOVÁ, Z. (2011). Konšpiračné teórie a ich argumentačné stratégie ako príklad ideologických diskurzov. In: Slovenský národopis. Vol. 59, No. 1, 2011, pp. 8-29.

PANCZOVÁ, Z. (2017). Konšpiračné teórie: témy, historické kontexty a argumentačné stratégie. Bratislava: VEDA, Ústav etnológie SAV, 2017, $160 \mathrm{pp}$.

PANCZOVÁ, Z. (2017a). The Image of the West in Conspiracy Theories in Slovakia and its Historical Context. In: Folklore. Vol. 69, 2017, pp. 49-68.

POMERANTSEV, P., WEISS, M. (2014). The Menace of Unreality: How the Kremlin Weaponizes the Information, Culture and Money. New York: Institute of Modern Russia, 2014, 44 pp.

REISIGL, M., WODAK, R. (2009). The Discourse-Historical Approach (DHA). In: MEYER, M., WODAK, R., (eds.). Methods for Critical Discourse Analysis. London: SAGE, 2009, pp. 87-122.

REŽO, J. (2018). Česko aj Slovensko zvažujú riadenú migráciu pracovnej sily a Sorosov prejav. In: Zem a Vek. [online]. Available at: <https://zemavek. sk/cesko-aj-slovensko-zvazuju-riadenu-migraciu-pracovnej-sily-asorosov-prejav-2/>. [Accessed 19.6.2018].

SLOBODA, P. (2017). Rusko sa stáva krízovým manažérom v Stredomorí. In: Zem a Vek. [online]. Available at: <http://zemavek.sk/articles/view/ruskosa-stava-krizovym-manazerom-v-stredomori>. [Accessed 7.2.2017].

SLOBODA, P. (2017a). Európska únia si naložila prit’ažký náklad, Afriku. In: Zem a Vek. [online]. Available at: <http://zemavek.sk/europska-unia-sinalozila-pritazky-naklad-afriku/>. [Accessed 4.12.2017].

SLOBODA, P. (2018). Nevoňajú vám prerozdelovacie kvôty? Zapojte sa do presídlovacieho programu. In: Zem a Vek. [online]. Available at: <https:// zemavek.sk/nevonaju-vam-prerozdelovacie-kvoty-zapojte-sa-dopresidlovacieho-programu/>. [Accessed 27.4.2018].

STRÁŽAN, R. (2017). Taliansky vyšetrovatel: „Mimovládky“ zabezpečujú prevoz migrantov do EÚ. In: Zem a Vek. [online]. Available at: <http:// zemavek.sk/articles/view/taliansky-vysetrovatel-mimovladkyzabezpecuju-prevoz-migrantov-do-eu>. [Accessed 21.4.2017].

STRUHÁRIK, F. (2019). MediaBrífing: Prečo sú Hlavné správy ideálnym partnerom pre Fica a Kočnera (grafy a fakty). In: Denník N. [online]. Available at: <https://dennikn.sk/1630470/mediabrifing-preco-suhlavne-spravy-idealny-partner-pre-fica-a-kocnera-grafy-a-fakty/>. [Accessed 25.10.2019]. 
ŠTEVKO, L'. (2018). Kampaň za prijatie sýrskych sirôt je falošná solidarita. In: Hlavné správy. [online]. Available at: <https://www.hlavnespravy. sk/kampan-za-prijatie-syrskych-sirot-je-falosna-solidarita/1555609>. [Accessed 19.10.2018].

TAJFEL, H., TURNER, J. (2004). The Social Identity Theory of Intergroup Behavior. In: JOST, J. T., SIDANIUS, J. (eds.). Political Psychology: Key Readings. New York: Psychology press, 2004, pp. 276-293.

TYDLITÁTOVA, V. (2017). Židé v Putinově stínu. Antisemitismus v české prokremelské propagandě. Plzeň: FF Západočeské univerzity v Plzni, 2017, $571 \mathrm{pp}$.

VAN PROOIJEN, J-W., VAN VUGT, M. (2018). Conspiracy Theories: Evolved Functions and Psychological Mechanisms. In: Perspectives on Psychological Science. Vol. 13, No. 6, 2018, pp. 1-19.

YABLOKOV, I. (2015). Conspiracy Theories as a Russian Public Diplomacy Tool: The Case of Russia today (RT). In: Politics. Vol. 35, No. 3-4, 2015, pp. 301-315.

YABLOKOV, I. (2018). Fortress Russia: Conspiracy Theories in the Post-Soviet World. Cambridge: Polity Press, 2018, 288 pp.

WATANABE, K. (2018). Conspiracist propaganda: How Russia promotes antiestablishment sentiment online? Hamburg: ECPR General Conference, 2018, 33 pp.

Zem a Vek. (2018). EÚ oficiálne prohlásila, že jejim cílem je přijmout 50 miliónu imigrantú. In: Zem a Vek. [online]. Available at: <https:// zemavek.sk/eu-oficialne-prohlasila-ze-jejim-cilem-je-prijmout-50milionu-imigrantu/>. [Accessed 3.8.2018]. 